\title{
The Money Should Be Base Point in the Economy
}

\section{Nodar Chinchaladze}

Economics, Business Administration, University of Georgia, Tbilisi, Georgia

Email address:

Amioni@amioni.ge, nodar.chinchaladze@gmail.com

\section{To cite this article:}

Nodar Chinchaladze. The Money Should Be Base Point in the Economy. International Journal of Sustainable Development Research. Vol. 7, No. 3, 2021, pp. 56-60. doi: 10.11648/j.ijsdr.20210703.12

Received: July 24, 2021; Accepted: August 9, 2021; Published: August 23, 2021

\begin{abstract}
In modern time the world really have forgotten what the money is. Why the humanity invented it, what was (and should be) its function in the society? Maybe it is better to compare this tool to other inventions done during centuries, used and developed? Why the society was developing the used units to make them as exact as possible? Here is a trial to show that the society step by step developed the tools of social cooperation. Mainstream goal always was to find better possibility to make honest contracts, to do easy exchanges, to trade easily. To look at in history it is possible to see how it was changing all the measurement units during time: many different measure unit of weight mainly came into one precise $\mathrm{kg}$, many different measurement units of length mainly came into one precise Meter, many different measurement units of time came to second, so, nowadays $\mathrm{kg}$, meter, second and some more different units are most precise ones and used by humanity as they are very usable in the contracts. The money too, in the $19^{\text {th }}$ century came to gold (and silver) and became most trustable tool of measurement of value. And something happened in $20^{\text {th }}$ century, something what the money did not deserve. Modern world has stepped back in case of money.
\end{abstract}

Keywords: History and Money, Stability of Money, Durability of Money, Political Temperature, Value of Money, Time and Money, Devaluation, Role of Measuring

\section{Introduction}

Give me a place to stand and I will move the world [23], has said Archimedes.

In modern days it becomes harder and harder to find the reason why the economy goes wrong in some cases. Many different experts find many different reasons but anyway time by time the crisis comes again and again. In the article "The impact of various currency regimes on economic development facets: case of Georgia" is written:

"After each crisis supporters of the Federal Reserve System argued that the crisis would be even heavier if no active intervention and preliminary measures were taken. But Milton Friedman was of totally different opinion:

"These arguments are ultimately wrong. The fact is that the major depression and other periods of partial unemployment are the result of wrong management by the government itself and not the inward instability of the private economy. The agency established by the Government: Federal Reserve System to which was transferred responsibility for monetary policy. In 1930 and 1931, it managed to make as much as what would have been a slight cut in the economy, turning it into a tremendous catastrophe." [15]. Despite the fact that the arguments of supporters of the golden standard seem to be more serious about the background of the existing problems, there is no sign that the issue of this dispute will soon reach a consensus. Even Alan Grinspen (who later became the chairman of the Federal Reserve System in 1987-2006, for the whole 19 years) noted: "It is against the supporters of the welfare state as the golden standard stands against 'mysterious' simple scheme of seize. Deficit spending is a simple scheme of 'hidden' deprivation of wealth. On the way to this insidious process, gold is as a defender of property rights. If each of us are going to understand this tricky plan, it will not be difficult to imagine the aggression of the state intervention towards the golden standard" [17]. Hayek pointed out that the problem comes from old superstition about money and blamed Keynes for current problems: "The head of the current monetary problems is associated with Keynes and his disciples who have given scientific power to the centuries-old prejudice - 
long-term prosperity and full-scale employment" [16]. Hayek believes that the only way to a healthy monetary system is the competition: "When the government and other money-straping institutions are in a healthy competition with each other for long-term contracts, long-term stability is expected" [16]. But it is hard to imagine how such a condition can be reached in the current world. In reality have inflationary money like which has never existed before: "For centuries, in various societies the role of money was played by wheat, precious metals, sheep, sinks and others. However, gold and silver assumed the function of money best. The vast majority of countries speaking different languages have unanimously recognized the use of the gold as money, compared to other goods, which made gold (and partially silver) as world's money centuries ago. Society has never created a need for modern monetary policy, as the society was never bothered with inflation in the conditions of the market value of money, even though the banking system was free of pressure from any central bank. Inflation is the result of unnecessary mass of money and the bank itself is the source of additional money emissions" [19]. And now humanity has the system about which Mises mentioned: "The gold standard for determining the changes in purchasing power is completely separated from the political arena. It relies on the recognized truth that one person cannot make all people rich by printing money. The hatred for the gold standard is determined by the prejudice that governments can create a wealth by small piles of paper" [18]. Some authors have more radical views on this subject, indicating that this kind of monetary system is fraud against savers and last receivers: "Accepting money until it is gradually expanded into the entire system of economy, changing the prices and eventually increases the general level of prices, the rate of fraudulently reduced interest rate in receiving credit. So, they are reaching in the expense of savers or last receivers or at the expense of those who cannot get the money at all" [18]". [14]

Only the gold standard was saving individuals from the problems described above (gold standard - "most famous monetary system" [12]).

What is going on, "They are whether that stellar performance will also leave a lasting legacy, and what that legacy might or should be." [1]. And "20 years after the Asian Financial Crisis" [2] the question stays on to discuss again and again.

Yes, the money's reliability is very big problem for the most of people and it is so easy to see if one would like to see.

\section{Physical Unit - Liter}

\subsection{Units Are the Needs of Mankind}

We, human beings are exchanging some goods with each other differently from all living creatures. And this is main reason why we are humans and why we have civilization in that form as it is now. For the purpose of exchange human invented measuring tools: weight, length, volume, time, value and so on. Step by step human tried to make the tools more and more exact. So, humanity got result: we have kg, meter, second, liter and so on, quite exact tools of measurements. Most of modern world uses this standard measurement. And even that countries still use other measuring units, they strongly have defined connection to this measure units. (for example: 1 feet $=0.3048 \mathrm{~m}$ ). why the humanity tries to measure everything precisely? - because to make contract between two side cannot be honest without mostly exact measuring.

\subsection{Unit Liter Is Different in KGS Depending on Temperature, Presented in Figure}

There was needed to have connection between different measures. For example, humanity uses $\mathrm{kg}$ for weight and liter for volume. Everyone knows that $1 \mathrm{~kg}$ water is 1 liter but most people know that it is not exact, volume of water changes by temperature and pressure. For normal pressure its dependence on temperature looks like as it is given on this chart:

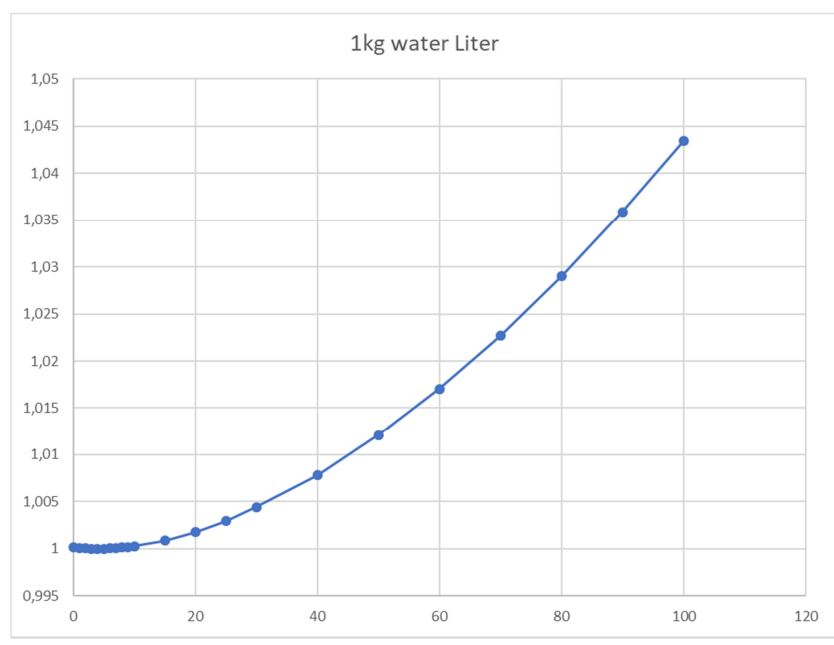

Figure 1. Volume of $1 \mathrm{~kg}$ water by temperature. [22]

\subsection{Unit Liter Is Different in KGS Depending on Temperature, Presented in Formulas}

It is visible from this chart that the volume of $1 \mathrm{~kg}$ water is maximum on high temperature. For example: on the 100 degree of Celsius it is 1.043427 liter, on the 0 degree of Celsius it is 1.00013 liter, on the 4 degree of Celsius it is 1 liter. 1 liter is minimum volume for the $1 \mathrm{~kg}$ water. We can calculate alteration for water volume in the range $0-100$ degree of Celsius:

$$
\text { alteration }=\left(\frac{\text { maximum }}{\text { minimum }}-1\right) * 100 \%
$$

We mentioned that minimum volume for $1 \mathrm{~kg}$ water is 1 liter, maximum volume in the range $0-100$ is at the maximum of physical temperature and it is 1.043427 liter. Let sign alteration as A. so we will have:

$$
A=\left(\frac{1.043427}{1}-1\right) * 100 \% \approx 4.34 \%
$$

Maximum alteration is $4.34 \%$ for water, not big alteration but it may be very important when people trade with liquid 
(certainly other liquids have another alteration, but not important to mention about that here). So, the traders take cares in which degree how to calculate the price by volume. We need take care that here was calculated alteration for range 0 to 100 degree which is maximum range for liquid water but usually never comes in reality in case of trades.

\section{USD Dollar}

\subsection{US Dollar's Value in 1813-1913}

Value of goods (here and everywhere below goods=goods and/or service) is also question of measuring. Humanity fnd way to measure it trying many different ways, in different period of history for measuring the value of goods was used: salt, sinks, rice, grain, cow and so on. At last it was found that most precise tool for measuring and it was gold (also silver and some other metals). In reality, gold is quite good choice: it is quite rare in nature, dividable, durable and so on.
And also "The gold standard for determining the changes in purchasing power is completely separated from the political arena. It relies on the recognized truth that one person cannot make all people rich by printing money. The hatred for the gold standard is determined by the prejudice that governments can create a wealth by small piles of paper" [11].

So, as Maslow says, motivation stimulated and [9] it happened that mostly all the world began to use gold as tool for measuring of value of goods, let say it was gold pricing era. Turning points from this era to modern model was 1913 and 1971, in 1913 in USA was established FED (or FRS, Federal Reserve System) and in 1971 was cut last knit of the connection between US dollar and gold. So, thinking about money alteration mindful to count value of money comparing to value in 1913. Let mark it as USD1913 and let say USD1913=1. In this case we have chart for US dollar for 1813 - 1913 like this:

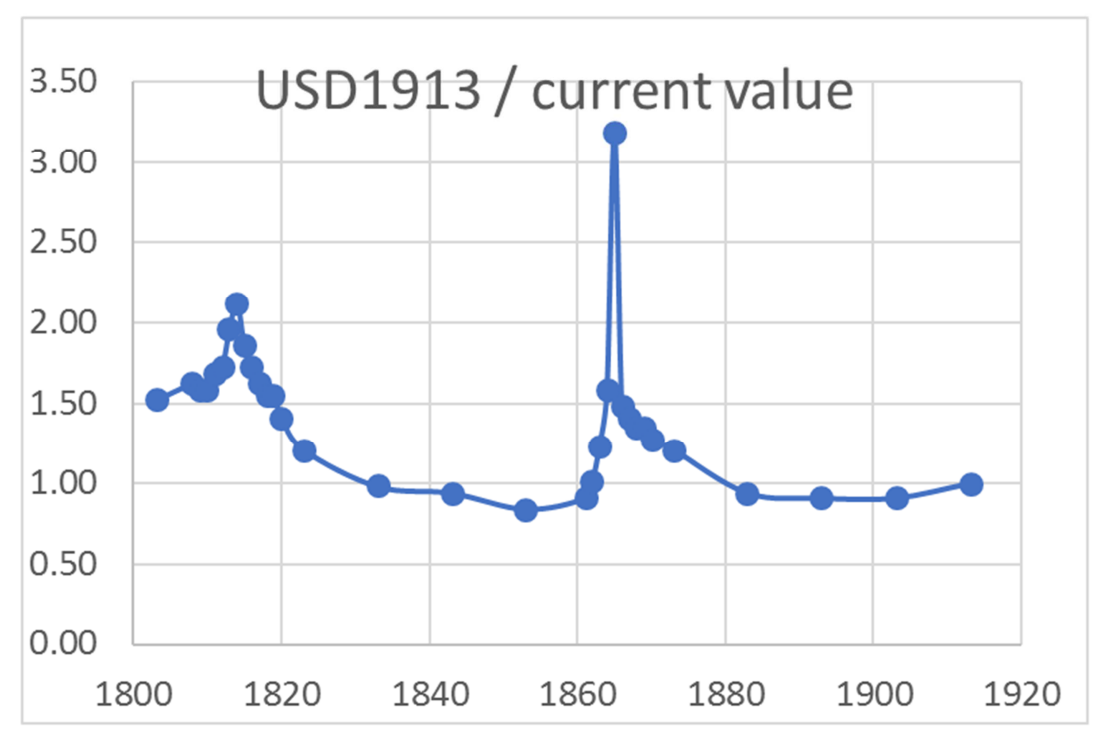

Figure 2. US dollar's value comparing to USD1913 for the period 1813-1913. [20]

Let find alteration for USD for this period:

$$
A=\left(\frac{\text { maximum }}{\text { minimum }}-1\right) * 100 \%=\left(\frac{3.19}{0.84}-1\right) * 100 \% \approx 279.21 \%
$$

Quite big alteration comparing to the liquid's A. but here is valuable to mention that the maximum alteration comes because of wars when political temperature was very high. If we exclude the periods of wars the alteration is not so big, it would be $88,70 \%$, not as small number as liquid's one but anyway. And more important here is the fact that after the war when the political temperature fells down value of money turns back to its previous value. The money in that period was durable and trustable and quite stable.

\subsection{US Dollar's Value in 1913-2013}

Now let see the chart for the period 1913-2013:

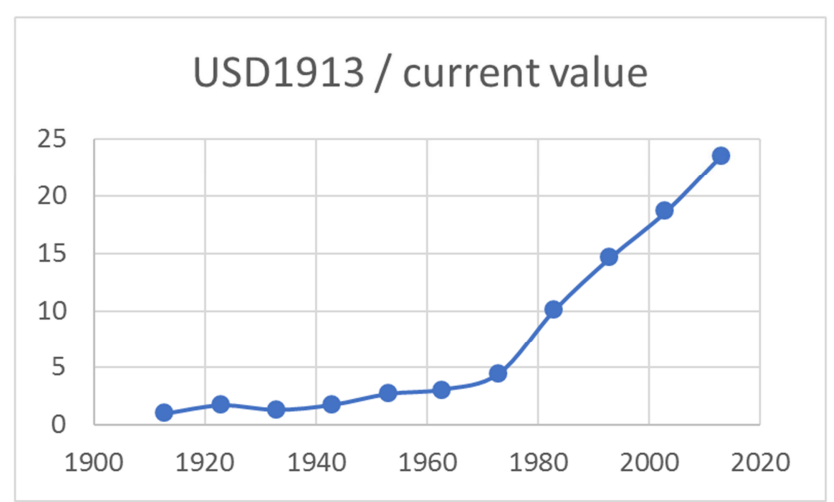

Figure 3. US dollar's value comparing to USD1913 for the period 1913-2013. [21] 
After calculating alteration by the same way as above, we will have $2253 \%$. Even if we exclude the World War 1 and World War 2, the number 2253 will stay same as the maximum alteration is not on the period of war but at the end of the period, 1USD1913 = 23.53USD2013. and very interesting point here that it never turns back, next time alteration become bigger and bigger (for example 1USD1913=25.87USD2019. Step by step, movement is to only one direction - devaluation.

\subsection{US Dollar's Value in 1913-2013}

Even if we look up for full period of 1813-2013, the picks of $19^{\text {th }}$ century is too little to mention:

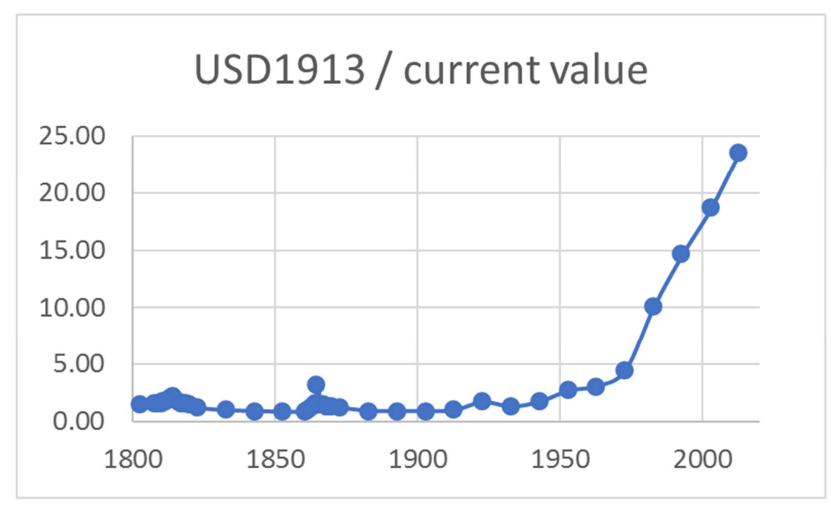

Figure 4. US dollar's value comparing to USD1913 for the period 1813-2013. [21]

During centuries humanity tried to find tools to measure weight, meter, volume, value and other measures more and more precisely. Finding one there were try to find better and more exact tools. And, so step by step there was found mostly very precise measuring tools system for not, to lie each other when people exchange some goods between each other. Only in case of value of money there was lost what already was found, current money (US dollar) is worse than the one in $19^{\text {th }}$ century. Money, what is the base of economy and should be durable for long time is not stabile but with stabile devaluation. And considering that what was said above, this process is used by some people to cheat others (saying it is necessary for economic prosperity, economic needs more money, small inflation stimulates the economy and so on).

The described circumstances are for US dollar but the condition in other countries is mostly worse, in some cases much worse. So, it comes to dispute: "Transfer credit risk, as an effective and modern concept..." [3], "The Economic of Inflation, a study of currency depreciation in post war Germany" [4], "The Economics of Inflation" [5], and what happened and why before East Asian Financial Crisis [13], "Classification of Exchange Rate Arrangements and Monetary Policy Frameworks" [8].

Some countries decide to anchor their currency to a more stable money what about worked Hanke [7], Meissner [10], and others.

Some countries find better way: Montenegro's currency reforms [7], and Economic policy in dollarized economies with a special review of Montenegro [6] is a sample, using
Euro as own currency, but it does not avoid problems of Euro, they still remains.

The information about different countries is given in The Annual Report on Exchange Arrangements and Exchange Restrictions has been published by the IMF since 1950. [8]

Shortly, in modern time only Swiss Franc somehow keeps its function of real money [19] (it is visible if check the inflation calculator online [24]).

\section{Conclusion}

In reality it is fact that humanity during all the history tried to find exact measurement systems for not to have losses after trade. And fundament of that is money, money should be most trustable, durable base of economy. And nowadays it is time to rebegin searching for the better means of exchange, it is time of question to show: is it way back to the gold system or way ahead to crypto currency or maybe something like crypto commodity. Only the thing definitely known is that humanity needs better Means of exchange than any existing currency in the modern world.

\section{References}

[1] Alan S. Blinder, P. U. (2005, 09). Understanding the Greenspan Standard. Princeton: Princeton University. Retrieved from ww.princeton.edu: https://www.princeton.edu/ceps/workingpapers/114blinderreis .pdf.

[2] ASDI, A. D. (Director). (2017). 20 Years after the Asian Financial Crisis: Lessons, Challenges, and the Way Forward day 1 [Motion Picture]. Retrieved from https://www.youtube.com/watch?v=lf4fnBfZOzI.

[3] Borislav Radevic, A. L. (2010). CREDIT RISK TRANSFER AS A MECHANISM OF PROTECTION AGAINST RISKS. Novi Pazar, Serbia.

[4] Bresciani-Turroni, C. ([1931]). The Economic of Inflation, a study of currency depreciation in post war Germany. (M. E. Sayers, Trans.) London: George Allen \& Unwin LTD.

[5] Bresciani-Turroni, C. (1937). The Economics of Inflation. Retrieved from archive.org: https://archive.org/stream/in.ernet.dli.2015.89882/2015.89882. The-Economics-Of-Inflation-A-Study-Of-Currency-Depreciat ion-In-Post---War-Germany\#page/n5/mode/2up.

[6] Fabris N., Vukajlovic-Grba D., Radunovic T., Jankovic J. (Podgorica 2004) ECONOMIC POLICY IN DOLLARIZED ECONOMIES WITH A SPECIAL REVIEW OF MONTENEGRO. The central bank of Montenegro.

[7] Hanke, S. (2019, May). REMEMBRANCES FROM MONTENEGRO'S MOMENTOUS CURRENCY REFORM: THE 1999 ADOPTION OF THE GERMAN MARK. Studies in Applied Economics. SAE/No. 135, pp. 1-8.

[8] IMF. (2004, 06 30). Classification of Exchange Rate Arrangements and Monetary Policy Frameworks. Retrieved $02 \quad 18, \quad 2018,2$ from IMF: https://www.imf.org/external/np/mfd/er/2004/eng/0604.htm. 
[9] Maslow, A. H. (n.d.). Religions, Values, and Peak Experiences.

[10] Meissner, C. M. (2008, 05 18). Why Do Countries Peg the Way They Peg? The Determinants of Anchor Currency Choice. Retrieved 02 18, 2018, from IMF: https://www.imf.org/external/pubs/ft/wp/2008/wp08132.pdf.

[11] Mises, L. v. (2010). To Protect the Barbarian Remnant: Why the Enemies of Capitalism Fell the Gold Standard. Library of Liberty, book VII / Georgian edition, lpp. 148-150.

[12] Officer, L. H. (2018, 03 03). Gold Standard. Retrieved from EH.net: http://eh.net/?s=gold+standard.

[13] Rana, P. B. (1999, February). East Asian Financial Crisis - An Agenda for Economic Recovery. Retrieved from Economics and Development Resource Center, Asian Development Bank, EDRC Briefing Notes Number 7: https://www.adb.org/publications/east-asian-financial-crisis-ag enda-economic-recovery.

[14] Chinchaladze, N. (2020). The Impact of various currency regimes on economic development facets: case of Georgia. Vilnius, Lithuania. Retrieved from http://jssidoi.org/jssi/papers/papers/view/554.

[15] Friedmen, M. (2002). Capitalism and Freedom. Tbilisi: Dilis Gazeti, Georgian edition.
[16] Hayek, F. (2016). Choice in Currency: A Way to Stop Inflation. Why I am not conservative and other essays (lpp. 280-301). Tbilisi: University of Georgia / Georgian edition.

[17] Greenspan, A. (2010). Gold and Economic Freedom. Librery of Liberty, Book VII, Money of Liberty / Georgian edition, pp. 143-147.

[18] Hoppe, H.-H. (2010). Bank systems, national governments and international policy: Sociological Reconstruction of the Current Economic Order. Library of Liberty, book VII / Georgian edition, lpp. 162-186.

[19] Tsomaia, A. (2010). Modern Monetarism and Economic Freedom. Librery of Liberty, Book VII, Money of Liberty / Georgian edition, lpp. 213-232.

[20] https://westegg.com/inflation/.

[21] http://www.usinflationcalculator.com/.

[22] http://www.ucdsb.on.ca/tiss/stretton/Database/DofWater.htm.

[23] https://www.math.nyu.edu/ crorres/Archimedes/Lever/Lever Quotes.html.

[24] https://www.in2013dollars.com/switzerland/inflation. 